\title{
HIGHLIGHT
}

\section{Cytotoxic luteinizing hormone-releasing hormone conjugates and their use in gynecological cancer therapy}

\author{
C Gründker \\ Department of Gynecology and Obstetrics, Georg-August University, Robert-Koch-Street 40, D-37075 Göttingen, Germany \\ (Correspondence should be addressed to C Gründker, Email: grundker@med.uni-goettingen.de)
}

Endometrial cancer is the most frequent malignant gynecological tumor in the western world. In most cases, it is diagnosed at an early stage when surgery alone or in combination with radiotherapy can achieve high cure rates (1). However, steroid receptor-negative tumors in elderly women or at advanced stages are rarely cured (2-4). Ovarian cancer is less frequent than endometrial cancer, but it is the most common cause of death from gynecological neoplasms (5). Effective regimens for surgery and first line cytotoxic chemotherapy are established, but in advanced or relapsed cases curative or palliative treatments with long term efficacy remain to be established (6-8). In both endometrial and ovarian cancer, new therapeutic strategies are required that are well tolerated and more efficacious.

Cytotoxic drugs are used as single agents or as combinations of several antitumor agents with different mechanisms of action. This chemotherapy is limited by its toxicity to normal cells. A more selective delivery of the cytotoxic agents to the tumor cells would allow the use of increased doses and would reduce the toxicity to normal cells.

In earlier studies it was shown that breast, ovarian, endometrial, pancreatic, and prostatic cancers express specific binding sites for luteinizing hormone-releasing hormone (LHRH) (9-16). Although these LHRH binding sites had a molecular mass comparable with that of pituitary LHRH receptor, their binding characteristics were of the low-affinity/high-capacity type (11, 15-17). Later, it became evident that in breast, ovarian, endometrial and prostate cancer cell lines, as well as in respective biopsy samples two types of LHRH binding sites exist, one of low affinity and high capacity, the other of high affinity and low capacity. The latter is comparable to the pituitary LHRH receptor $(11,15,16)$. In 1992, the cloning, sequencing and expression of the human pituitary LHRH receptor was reported (18). In the same publication, the authors reported the expression of mRNA for the human LHRH receptor in the breast cancer cell line, MCF-7. These findings stimulated intensive research leading to the demonstration of LHRH receptor gene transcripts in ovarian and endometrial cancer cell lines and in about $80 \%$ of the respective primary tumors $(16,19-21)$. In ovarian and endometrial cancer specimens and cell lines expressing mRNA for the pituitary LHRH receptor, highaffinity/low-capacity binding sites were found closely related to the pituitary LHRH receptor (19-23). Kakar et al. (24) demonstrated that the nucleotide sequence of LHRH receptors in human breast and ovarian tumors is identical to that found in pituitary. Data available today suggest that about $50 \%$ of breast cancers (25) and approximately $80 \%$ of ovarian and endometrial cancers express high-affinity binding sites for LHRH. For prostate cancer fewer findings have been published (15), but systematic investigations might lead to comparable results.

Since over $80 \%$ of human ovarian and endometrial cancers express receptors for LHRH, but most of human normal tissues do not express LHRH receptors (P Völker, C Gründker \& G Emans, unpublished results), LHRH receptors on tumor cells might be used for targeted chemotherapy. This should improve antitumor effects and reduce side effects compared with systemic conventional cytotoxic chemotherapy (26). LHRH analogs covalently linked to cytotoxic radicals could bind specifically to LHRH receptors with their peptide moiety and act as chemotherapeutic agents after internalization of the ligand-receptor complex into cancer cells or by acting at the membrane level. In this fashion, these conjugates can selectively affect those cells that possess LHRH receptors and thus exert fewer side effects than unconjugated cytotoxic agents (27). A great variety of cytotoxic analogs containing different LHRH agonists and antagonists and different cytotoxic compounds including melphalan, cisplatinum, methotrexate and cyclophosphamide derivatives have been synthesised in the past years (28-31). Most of these compounds preserved their LHRH analog action and were internalized into cells expressing receptors. Major problems, however, were caused by the instability of these compounds and the lack of preservation of their cytotoxic action (31-35). New cytotoxic analogs made of LHRH analogs having a D-Lys moiety in position 6, seem to solve these problems. This amino acid offers an amino side chain for convenient attachment of various cytotoxic compounds. It turns out that even bulky molecules could be linked to the $\epsilon$-amino group of the D-Lys ${ }^{6}$ moiety, without significant loss of binding affinity of the peptide portion to the receptors for LHRH (35-36).

Doxorubicin is the most widely used cytotoxic agent with a broad spectrum of antitumor activity (37). The strong antiproliferative effect of doxorubicin is mainly due to its ability to induce apoptosis. In some early 
conjugates, doxorubicin was linked to LHRH analogs using a glutaric acid spacer which formed carboxamide bonds between the daunosamine nitrogen of doxorubicin and the $\epsilon$-amino group of the D-Lys ${ }^{6}$ moiety of the carrier (38). The antiproliferative activity of doxorubicin was greatly reduced due to modification by the linkage. Since 14-O-esters of doxorubicin are stable and known to have similar antitumor effects to doxorubicin, doxorubicin-14-O-hemiglutarate was prepared which was, in turn, coupled to the $\mathrm{D}-\mathrm{Lys}^{6}$ side chain of the LHRH analog carriers (36). The cytotoxic hybrids obtained after deprotection fully preserved the cytotoxicity of doxorubicin and the binding affinity of the LHRH carriers. Recently, encouraging results have been made with the cytotoxic analogs AN-152 ([D-Lys $\left.{ }^{6}\right]-$ LHRH linked to doxorubicin) and AN-207 ([D-Lys $\left.{ }^{6}\right]$ LHRH linked to 2-pyrrolinodoxorubicin, a derivative of doxorubicin which is 500-1000 times more potent than its parent compound) (36). Results from proliferation assays suggest that, in LHRH receptor-positive ovarian and endometrial cancer cell lines, the effects of AN-152 are mediated through LHRH receptors. In these experiments, the cytotoxic effect of AN-152 was blocked by an excess of LHRH antagonists in the fashion of competitive inhibition. In 2 LHRH receptornegative cell lines tested, no indication of receptormediated action of AN-152 could be observed (39). Since most human normal tissues do not express LHRH receptors, a drug like AN-152 might provide the same cytotoxic activity as its cytotoxic moiety, doxorubicin, to the LHRH receptor-positive tumors while having significantly less effect on LHRH receptor-negative normal tissues. Observations using a confocal laser scanning microscope show a receptor-mediated action of AN-152 in LHRH receptor-positive cell lines, indicated by detection of $\mathrm{AN}-152$ in the nucleus of these cell lines which could be nullified by an excess of [D-Trp ${ }^{6}$ ]-LHRH. In LHRH receptor-negative cell lines, AN-152 could not be detected in the nucleus.

In rat pituitary cells AN-207 selectively and reversibly damages gonadotropes (40). In nude mice with an ovarian carcinoma xenograft expressing LHRH receptors, treatment with AN-207 significantly inhibited tumor growth, while the cytotoxic residue alone (2pyrrolino-doxorubicin) in equivalent doses was toxic to the animals and had no significant effect on tumor growth. Treatment with AN-207 downregulated receptors for LHRH and decreased epidermal growth factor receptor levels as well as expression of their mRNA (41). AN-152 had similar effects in LHRH receptorpositive OV-1063 ovarian cancer cell lines xenografted into nude mice. But no effect on tumor volume in LHRH receptor-negative UCI-107 cell lines was observed (42). AN-207 and AN-152 significantly inhibited tumor growth in LHRH receptor-positive MXT mouse mammary tumors while their respective cytotoxic residues alone were toxic to the animals without affecting tumor growth. In addition, a decrease of mitotic action and increasing apoptosis has been shown after treatment with cytotoxic LHRH analogs $(43,44)$. On the basis of its powerful inhibitory effect on the aggressive MXT mouse mammary tumor, AN207 could be considered as a treatment for advanced human breast cancers that express LHRH receptors.

A major problem of cytotoxic analogs is their stability in vivo. In long-time proliferation assays a growth inhibitory action of AN-152 could also be shown in receptor-negative cell lines. AN-152 might not be stable for the whole time that it is present in medium containing fetal calf serum (39). The antiproliferative effect of AN-152 in LHRH receptor-negative cell lines might be due to free doxorubicin, liberated from the peptide moiety by hydrolysis or enzymatic cleavage. In preliminary studies in vitro it was found that in serum of nude mice, rats, and humans the half-life $\left(t_{1 / 2}\right)$ of AN-152 was 10,30 , and 120 min respectively (36, 45). Serum carboxylesterase enzymes partially hydrolyse these conjugates in the circulation, releasing the cytotoxic radical before the targeting is complete. The very high carboxylesterase activity in nude mice, which is about 10 times higher than in the human (46) can be inhibited by the carboxylesterase inhibitor diisopropyl fluorophosphate. The addition of diisopropyl fluorophosphate to mouse serum in vitro results in a prolonged $t_{1 / 2}$ of AN-152 to 70 min and a better targeting for the cytotoxic conjugates (47). Since the disintegration of AN-152 can be slowed down by the carboxylesterase inhibitor diisopropyl fluorophosphate and, in addition, the effects of free doxorubicin are well known and doxorubicin has already been used in tumor therapy for some time, AN-152 should be useable as a first line tumor cell specific chemotherapeutic drug. It is different in the case of AN-207. The daughter product, AN-201, is many times more toxic than doxorubicin. Newer examinations show that AN-207 disintegrates very fast without the action of carboxylesterase enzymes. AN-207, therefore, does not seem to be suitable for first line chemotherapy.

In conclusion these data suggest a selective receptor mediated action of the cytotoxic LHRH analogs that could lead to target cell specific cytotoxic chemotherapy with the possibility of dose intensification and reduction of toxicity. The results of experimental studies in breast, ovarian and endometrial cancer models demonstrate the capability of cytotoxic LHRH analogs to inhibit growth and even cause regression of these tumors.

\section{References}

1 Westphalen S \& Emons G. GnRH analogues in ovarian, breast and endometrial cancers. In GnRH Analogues: The State of the Art at the Millennium, pp 105-120. Ed B Lunenfeld. New York, USA: Pantheon Publishing, 1999.

2 Emons G, Ortmann O, Schulz K-D \& Schally AV. Growth-inhibitory actions of analogues of luteinizing hormone-releasing hormone on tumor cells. Trends in Endocrinology and Metabolism $1997 \mathbf{8}$ 355-362. 
3 Ho MN, Delgado CH, Owens GA \& Steller MA. Insulin-like growth factor-II participates in the biphasic effect of a gonadotropinreleasing hormone agonist on ovarian cancer cell growth. Fertility and Sterility 199767 870-876.

4 Emons G, Müller V, Ortmann O \& Schulz KD. Effects of LHRH analogues on mitogenic signal transduction in cancer cells. Journal of Steroid Biochemistry and Molecular Biology 199865 199-206.

5 Imai A, Takagi A, Horibe S, Takagi H \& Tamaya T. Evidence for tight coupling of gonadotropin-releasing hormone receptor to stimulated Fas ligand expression in reproductive tract tumors: possible mechanism for hormonal control of apoptotic cell death. Journal of Clinical Endocrinology and Metabolism $1998 \mathbf{8 3} 427-$ 431.

6 Imai A, Takagi A, Horibe S, Takagi H \& Tamaya T. Fas and Fas ligand system may mediate antiproliferative activity of gonadotropin-releasing hormone receptor in endometrial cancer cells. International Journal of Oncology 199813 97-100.

7 Yin H, Cheng KW, Hwa HL, Peng C, Auersperg M \& Leung PC. Expression of the messenger RNA for GnRH and its receptor in human cancer cell lines. Life Sciences 199862 2015-2023.

8 Seppälä M \& Wahlström T. Identification of luteinizing hormonereleasing factor and alpha subunit of glycoprotein hormones in ductal carcinoma of the mammary gland. International Journal of Cancer 198026 231-233.

9 Schally AV. Hypothalamic hormones from neuroendocrinology to cancer therapy. Anticancer Drugs 19945 115-130.

10 Stojilkovic SS \& Catt KJ. Expression and signal transduction pathways of gonadotropin-releasing hormone receptors. Recent Progress in Hormone Research 199530 161-205.

11 Emons G \& Schally AV. The use of luteinizing hormone-releasing hormone agonists and antagonists in gynecological cancers. Human Reproduction 19949 1364-1379.

12 Friess H, Buchler M, Kiesel L, Krüger M \& Berger HG. LH-RH receptors in the human pancreas. Basis for antihormonal treatment in ductal carcinoma of the pancreas. International Journal Pancreatology 199110 151-159.

13 Baumann KH, Kiesel L, Kaufmann M, Bastert G \& Runnebaum B. Characterization of binding sites for a GnRH-agonist (buserelin) in human breast cancer biopsies and their distribution in relation to tumor parameters. Breast Cancer Research and Treatment 199325 $37-46$.

14 Dondi D, Limonta P, Moretti RM, Marelli MM, Garattini E \& Motta M. Antiproliferative effects of luteinizing hormone-releasing hormone (LHRH) agonists on human androgen-independent prostate cancer cell line DU 145: evidence for an autocrineinhibitory LHRH loop. Cancer Research $1994 \mathbf{5 4} 4091-4095$.

15 Loop SM, Gorder CA, Lewis SM, Saiers JH, Drivdahl RH \& Ostenson RC. Growth inhibition of human prostatic cancer cells by an agonist of gonadotropin-releasing hormone. Prostate 1995 26 179-188.

16 Gründker C \& Emons G. GnRH - mechanisms of action. In GnRH Analogues: The State of the Art at the Millennium, pp 7-29. Ed B Lunenfeld. New York, USA: Pantheon Publishing, 1999.

17 Fekete M, Redding TW, Comaru-Schally AM, Pontes JE, Connely RW \& Srkalovic G et al. Receptors for luteinizing hormone-releasing hormone, somatostatin, prolactin and epidermal growth factor in rat and human prostatic cancers and in benign prostatic hyperplasia. Prostate 198914 191-208.

18 Kakar SS, Musgrove LC, Devor DC, Sellers JC \& Neill JD. Cloning, sequencing, and expression of human gonadotropin-releasing hormone $(\mathrm{GnRH})$ receptor. Biochemical and Biophysical Research Communications 1992189 289-295.

19 Imai A, Ohno T, Iida K, Fuseya T, Furui $\mathrm{T}$ \& Tamaya $\mathrm{T}$. Gonadotropin-releasing hormone receptors in gynecological tumors. Cancer $1994 \mathbf{7 4} 2555-2561$.

20 Imai A, Ohno T, Iida K, Fuseya T, Furui T \& Tamaya T. Presence of gonadotropin-releasing hormone receptor and its messenger ribonucleic acid in endometrial carcinoma and endometrium. Gynecological Oncology 199455 114-118.
21 Irmer G, Bürger C, Müller R, Ortmann O, Peter U \& Kakar S et al. Expression of the messenger RNAs for luteinizing hormonereleasing hormone (LHRH) and its receptor in human ovarian epithelial carcinoma. Cancer Research 199555 817-822.

22 Emons G, Ortmann O, Becker M, Irmer G, Springer B \& Laun R et al. High affinity binding and direct antiproliferative effects of LHRH analogues in human ovarian cancer cell lines. Cancer Research $1993 \mathbf{5 4} 5439-5446$.

23 Emons G, Schröder B, Ortmann O, Westphalen S, Schulz KD \& Schally AV. High affinity binding and direct antiproliferative effects of luteinizing hormone-releasing hormone analogs in human endometrial cancer cell lines. Journal of Clinical Endocrinology and Metabolism 199377 1458-1464.

24 Kakar SS, Grizzle WE \& Neill JD. The nucleotide sequence of human GnRH receptors in breast and ovarian tumors are identical with that found in pituitary. Molecular and Cellular Endocrinology 1994106 145-149.

25 Fekete M, Wittliff JL \& Schally AV. Characteristics and distribution of receptors for $\left[\mathrm{D}-\mathrm{Trp}^{6}\right]$-luteinizing hormone-releasing hormone, somatostatin, epidermal growth factor and sex steroids in 500 biopsy samples of human breast cancer. Journal of Clinical Laboratory Analysis 19893 137-147.

26 Schally AV. Luteinizing hormone-releasing hormone analogs; their impact on the control of tumorigenesis. Peptides 199920 1247-1262.

27 Schally AV, Nagy A, Szepeshazi K, Pinski J, Halmos G \& Armatis P et al. LH-RH analogues with cytotoxic radicals. In Treatment with GnRH Analogs: Controversies and Perspectives, pp 33-44. Ed M Filicori \& C Flamigni. Canforth, UK: Parthenon Publishing, 1996.

28 Bajusz S, Janaky T, Csernus VJ, Bokser L, Fekete M \& Srkalovic G et al. Highly potent analogues of luteinizing hormone-releasing hormone containing D-phenylalanine nitrogen mustard in position 6. PNAS $1989 \mathbf{8 6} 6318-6322$.

29 Janaky T, Juhasz A, Bajusz S, Csernus V, Srkalovic G \& Bokser L et al. Analogues of luteinizing hormone-releasing hormone containing cytotoxic groups. PNAS 199289 972-976.

30 Milovanovic SR, Radulovic S \& Schally AV. Evaluation of binding of cytotoxic analogues of luteinizing hormone-releasing hormone to human breast cancer and mouse MXT mammary tumors. Breast Cancer Research and Treatment 199224 147-158.

31 Milovanovic SR, Monje E, Szepeshazi K, Radulovic S \& Schally AV. Effect of treatment with LHRH analogues containing cytotoxic radicals for luteinizing hormone-releasing hormone in MTX mouse mammary carcinoma. Journal of Cancer Research and Clinical Oncology 1993119 273-278.

32 Pinski J, Yano T, Janaky T, Nagy A, Juhasz A \& Bokser L et al. Evaluation of biological activities of new LH-RH antagonists (Tseries) in male and female rats. International Journal of Peptide and Protein Research 199341 66-73.

33 Rekasi S, Szöke B, Nagy A, Groot K, Rekasi ES \& Schally AV. Effect of luteinizing hormone-releasing hormone analogs containing cytotoxic radicals on the function of rat pituitary cells: tests in a long term superfusion system. Endocrinology 1993132 1991-2000.

34 Szöke B, Horvath J. Halmos G, Rekasi Z, Groot K \& Nagy A et al. $\mathrm{LH}-\mathrm{RH}$ analogue carrying a cytotoxic radical is internalised by rat pituitary cells in vitro. Peptides 199415 359-366.

35 Schally AV \& Nagy A. Chemotherapy targeted to hormone receptors on tumors. European Journal of Endocrinology 1999141 $1-14$.

36 Nagy A, Schally AV, Armatis P, Szepeshazi K, Halmos G \& Kovacs M et al. Cytotoxic analogues of luteinizing hormone-releasing hormone containing doxorubicin or 2-pyrrolinodoxorubicin, an analogue 500-1000 times more potent: structure-activity relationship of daunosamine-modified derivates of doxorubicin. PNAS $1996937269-7273$.

37 Weiss RB. The anthracyclines: will we ever find a better doxorubicin? Seminars in Oncology 199219 670-686.

38 Janáky T, Juhász A, Bajusz S, Csernus V, Srkalovic G \& Bokser L et al. Analogues of luteinizing hormone-releasing hormone containing cytotoxic groups. PNAS 199289 972-976. 
39 Westphalen S, Kotulla G, Kaiser F, Krauß W, Werning G \& Elsässer HP et al. Receptor mediated antiproliferative effects of the cytotoxic LHRH agonist AN-152 in human ovarian and endometrial cancer cell lines. International Journal of Oncology (In Press).

40 Kovacs M, Schally AV, Nagy A, Koppan M \& Groot K. Recovery of pituitary function after treatment with a targeted cytotoxic analog of luteinizing hormone-releasing hormone. PNAS 1997 94 1420-1425.

41 Miyazaki M, Schally AV, Nagy A, Lamharzi N, Halmos G \& Szepeshazi K et al. Targeted cytotoxic analogue of luteinizing hormone-releasing hormone AN-207 inhibits growth of OV-1036 human epithelial ovarian cancers in nude mice. American Journal of Obstetrics and Gynecology $1999 \mathbf{1 8 0}$ 1095-1103.

42 Miyazaki M, Nagy A, Schally AV, Lamharzi N, Halmos G \& Szepeshazi K et al. Growth inhibition of ovarian cancers by cytotoxic analogues of luteinizing hormone-releasing hormone. Journal of the National Cancer Institute 199789 1803-1809.

43 Szepeshazi K, Schally AV, Nagy A, Halomos G \& Groot K. Targeted cytotoxic luteinizing hormone-releasing hormone analogue inhibits growth of estrogen independent MXT mouse mammary cancers in vivo by decreasing cell proliferation and inducing apoptosis. Anticancer Drugs 19978 974-987.
44 Szepeshazi K, Schally AV \& Nagy A. Effective treatment of advanced estrogen-independent MXT mouse mammary cancers with targeted cytotoxic LH-RH analogs. Breast Cancer Research and Treatment 199956 267-276.

45 Plonowski A, Schally AV, Nagy A, Sun B \& Szepeshazi K. Inhibition of PC-3 human androgen-independent prostate cancer and its metastases by cytotoxic somatostatin analogue AN-238. Cancer Research 199959 1947-1953.

46 Kaliste-Korhonen E, Tuovinen K \& Hänninen O. Interspecies differences in enzymes reacting with organophosphates and their inhibition by paraoxon in vitro. Human Experimental Toxicology $199615972-978$

47 Nagy A, Ploniowski A \& Schally AV. Stability of cytotoxic luteinizing hormone-releasing hormone conjugate (AN-152) containing doxorubicin 14-O-hemiglutarate in mouse and human serum in vitro: implications for the design of preclinical studies. PNAS 200097 829-834.

Received 2 August 2000

Accepted 4 August 2000 